\title{
Sensitivity of the Colletotrichum acutatum Species Complex From Apple Trees in Brazil to Dithiocarbamates, Methyl Benzimidazole Carbamates, and Quinone Outside Inhibitor Fungicides
}

\author{
Rafaele R. Moreira ${ }^{1, \dagger}$, Natasha A. Hamada ${ }^{1}$, Natalia A. Peres ${ }^{2}$, and Louise L. May De Mio ${ }^{1}$ \\ ${ }^{1}$ Universidade Federal do Paraná, Setor de Ciências Agrárias (SCA-DFF), Curitiba, PR 80035-050, Brazil \\ ${ }^{2}$ University of Florida, Gulf Coast Research and Education Center (GCREC-UF), Wimauma, FL 33598, U.S.A.
}

\begin{abstract}
Glomerella leaf spot (GLS) and bitter rot (BR) on apples are often caused by Colletotrichum acutatum in Paraná State, Brazil. GLS control is difficult because of its rapid development, with an incubation period of only 2 days under favorable conditions. Therefore, producers use successive fungicide applications every season; however, failure to control GLS has been commonly reported. The objectives of this study were to determine the sensitivity of isolates of the $C$. acutatum species complex obtained from apple orchards in Brazil to mancozeb, thiophanate-methyl, and azoxystro-

sensitivity to mancozeb, thiophanate-methyl, and azoxystrobin. For mancozeb, the frequencies of isolates were $25 \%$ highly resistant, $50 \%$ lowresistance, and $25 \%$ sensitive. For thiophanate-methyl, the frequencies of isolates were $72.2 \%$ highly resistant, $11.1 \%$ resistant, and $16.7 \%$ moderately resistant. For azoxystrobin, the frequencies of isolates were $11.1 \%$ highly resistant, $5.6 \%$ resistant, and $83.3 \%$ sensitive. Interestingly, no mutations in the $\beta$-tubulin and cytochrome $b$ genes were observed in any of the isolates resistant to thiophanate-methyl and azoxystrobin fungicides.
\end{abstract} bin fungicides. Isolates from the different parts of the plant (leaves, flowers, buds, and twigs) and cultivars (Gala and Eva) showed different levels of

Keywords: chemical, disease management, fruit, fungi, tree fruits

Colletotrichum is one of the most economically important fungal pathogens causing anthracnose on fruit and leaves of a broad range of hosts in tropical and subtropical regions (Bragança et al. 2016; Cannon et al. 2012; Sutton et al. 1992). On apple (Malus domestica Borkh.), several species of the genus cause Glomerella leaf spot (GLS) on leaves and fruit and bitter rot (BR) on fruit (González et al. 2006). In Paraná State, Brazil, most isolates that cause GLS and BR belong to the Colletotrichum acutatum species complex (Moreira et al. 2019).

GLS is a foliar disease that was first reported in 1970 in the United States (Taylor 1971). It remained economically unimportant until it caused serious outbreaks in apple orchards in 1998 (González and Sutton 2004). In Brazil, GLS appeared in 1983; over the years, its intensity increased continuously. It is currently one of the main diseases affecting orchards in the southern region (Moreira et al. 2014; Moreira and May De Mio 2015; Sutton and Sanhueza 1998; Velho et al. 2015). GLS symptoms appear on leaves as purple-red spots that usually develop into irregular necrotic lesions after 7 to 10 days, and leaves often turn yellow and fall prematurely (Hamada 2013). On fruit, the pathogen may cause small, brown, slightly depressed spots ( 1 to $3 \mathrm{~mm}$ ) that do not increase in size over time (Sutton and Sanhueza 1998). Apple cultivars descended from the 'Golden Delicious' group, such as the cv. Gala, are highly susceptible to this disease (Stadnik et al. 2009). Cultivar Eva (Anna $\times$ Gala) has been reported to be resistant (Furlan et al. 2010); however, symptoms have been observed in Parana and Colletotrichum spp. isolates were obtained (Hamada 2013).

${ }^{\dagger}$ Corresponding author: R. R. Moreira; rafaelemor@gmail.com

Funding: This study was financed in part by the Coordenação de Aperfeiçoamento de Pessoal de Nível Superior - Brazil (CAPES) - Finance Code 001 and by the Conselho Nacional de Desenvolvimento Científico e Tecnológico Brazil (CNPq).

The author(s) declare no conflict of interest.

Accepted for publication 2 May 2019.

(C) 2019 The American Phytopathological Society
BR affects apple fruit and occurs in most countries where apples are grown (Alaniz et al. 2012; González and Sutton 2004; Shi et al. 1996; Zhang et al. 2008). It has a greater destructive potential than any other apple rot and can result in losses up to $50 \%$ before and after harvest (Sutton et al. 1992). BR was first described in England in 1956, and one decade later in the United States (Taylor 1971). In Brazil, the disease appeared in the 1970s, when commercial apple production was introduced in the country (Denardi et al. 2003).

GLS and BR are often observed in the subtropics, where rain and warm weather favor the spread of conidia and the development of symptoms. Management of GLS and BR is difficult because of the rapid development of these diseases; the incubation period under favorable conditions is only 2 days for GLS (Leite et al. 1988; Moreira and May De Mio 2015) and for BR on wounded fruit (Moreira and May De Mio 2015). Given the combination of the rapid onset of symptoms and the favorable climate for the development of diseases in subtropical climates, the most effective control practice is the intensive use of fungicides. In general, fungicide applications are performed preventively every 5 to 10 days or after events of rain more $25 \mathrm{~mm}$, from budburst to harvest (Katsurayama and Bonetti 2009). In favorable climates, such as in Paraná State, spraying for GLS is extended until the postharvest period in mid-autumn to avoid early defoliation of the plant and to ensure growth and production during the following year (Hamada et al. 2012). This regimen results in a large number of fungicide sprays, with an average of $>20$ applications per season of protective fungicides such as dithiocarbamates (mancozeb, metiram, propineb) and up to eight applications per season of systemic fungicides such as methyl benzimidazole carbamates (thiophanate-methyl, carbendazim) and quinone outside inhibitors (QoIs; pyraclostrobin, trifloxystrobin, kresoxim-methyl) (Hamada and May De Mio 2017). The active ingredients listed here are those registered for use on apples in Brazil (Agrofit 2019).

The use of protective fungicides involves a low risk of selection for pathogen resistance because they have a broad spectrum of action that does not interfere with a specific metabolic process of the fungus (Brent and Hollomon 2007). However, there have been reports of Colletotrichum spp. on mango and citrus resistant to mancozeb in vitro (Kumar et al. 2007; Ling et al. 2010; Suvarna et al. 2009). These mancozeb resistance studies have been conducted using mycelial growth instead of inhibition of conidia germination, which might 
be more appropriate for this group of fungicides (Gullino et al. 2010; Ishii 2015), but the comparison between the two methodologies has not yet been performed. However, despite reports of resistance in vitro, field resistance (with reported loss of disease control) to mancozeb has not been reported in the literature. Nevertheless, some apple producers of Paraná State have reported that they have been using higher rates of this fungicide for better disease control in the field.

Systemic fungicides have specific modes of action and, therefore, a greater risk when selecting resistant individuals. The group of methyl benzimidazole carbamates (MBC) acts specifically on the synthesis of tubulin by inhibiting the binding of microtubules that form the mitotic spindle (Wheeler et al. 1995). Resistance to MBC fungicides is conferred as a result of point mutations in the $\beta$-tubulin gene, resulting in the alteration of amino acid sequences at the binding sites. The most common substitutions in resistant pathogens occur at codons 167, 198, and 200 of the $\beta$-tubulin gene (for example, F167Y, E198A/K, and F200Y). The F167Y and F200Y mutations result in the substitution of phenylalanine $(\mathrm{F})$ by tyrosine $(\mathrm{Y})$, and E198A/K mutation is a replacement of glutamic acid (E) to alanine (A) and lysine (K) (Ma et al. 2005). Several cases of MBC resistance have been reported for the $C$. gloeosporioides species complex, including crops such as citrus (Peres et al. 2004), pear (Kaneko et al. 2010; Tashiro et al. 2012), and apple (Hamada et al. 2009). However, isolates from the $C$. acutatum species complex have been shown to have naturally low sensitivity in vitro to MBC fungicides (Goes and Kimati 1998; Hwang et al. 2010; Kim et al. 2007; Peres et al. 2004).

Respiration-inhibiting fungicides such as the QoIs inhibit ATP production during mitochondrial respiration by binding to the quinone outside center on the cytochrome $b$ gene (Bartlett et al. 2002). Resistance to QoI fungicides is conferred as a result of point mutations in the cytochrome $\mathrm{b}$ gene, and the most common amino acid substitutions occur at positions F129L, G137R, and G143A (FRAC 2013; Gisi et al. 2002). QoI resistance has already been reported for Colletotrichum species, including C. graminicola on turf (Avila-Adame et al. 2003), C. gloeosporioides species complex (Ishii et al. 2007) and C. acutatum species complex (Forcelini et al. 2016) on strawberry, Venturia inaequalis on apple (Lesniak et al. 2011), Corinespora cassiicola on cucumber, Mycovellosiella nattrassii on eggplant (Ishii et al. 2007), Passalora fulva on tomato (Watanabe et al. 2017), and Podosphaera xanthii on cucurbit (Vielba-Fernández et al. 2018).

Despite the large number of fungicide applications, control of GLS and BR in Paraná State has not been very effective, especially under highly favorable conditions such as rainy years with optimum temperatures (between 22 and $27^{\circ} \mathrm{C}$ ) (Boneti et al. 2004; Hamada

Table 1. Descriptions of the isolates of Colletotrichum acutatum species complex collected from apple groves in the state of Paraná, Brazil

\begin{tabular}{lcccc}
\hline Municipality & Year & Cultivar & $\begin{array}{c}\text { Part of the } \\
\text { plant }^{\mathbf{a}}\end{array}$ & Isolates \\
\hline $\begin{array}{l}\text { São Sebastião da } \\
\quad \text { Amoreira }\end{array}$ & 2010 & Eva & SL & $1-21$ \\
$\begin{array}{l}\text { Palmas } \\
\text { Campo Largo }\end{array}$ & 2011 & Gala & SL & $56-68$ \\
$*$ & 2011 & Gala & SL & $69-71$ \\
Campo Largo & 2010 & Gala & SL & col19 \\
Campo Largo & 2010 & Gala & DB & $48-55$ \\
& & Gala & DB & 114,115, \\
Campo Largo & 2011 & Gala & DT & $122-135$ \\
Campo Largo & 2011 & Gala & LG & $116-175$ \\
& & & & $136-153$ \\
Campo Largo & 2011 & Gala & FL & $176-181$ \\
\hline
\end{tabular}

${ }^{\mathrm{a}} \mathrm{LG}=$ leaves on the ground during the winter period, $\mathrm{SL}=$ symptomatic leaves, $\mathrm{FL}=$ flowers, $\mathrm{DB}=$ dormant buds, DT $=$ dormant twigs. Isolates $8,9,10,152$, and Col19 belonging to species $C$. paranaense and all the other isolates belonging to the $C$. nymphaeae species according to Moreira et al. (2019). *Isolates collected in the state of Paraná (with unknown municipality). et al. 2012). Therefore, it is important to determine the sensitivity of pathogen populations to the primary fungicides used for GLS and BR control in the Brazilian apple-producing areas to monitor the selection for resistant populations.

The objective of this study was to determine the sensitivity of isolates of the $C$. acutatum species complex obtained from different apple orchards in Brazil to representative fungicides in the dithiocarbamate, $\mathrm{MBC}$, and QoI fungicide groups.

\section{Materials and Methods}

A total of 114 isolates of Colletotrichum spp. were recovered from orchards in Paraná State during 2010 and 2011 from symptomatic leaves, dormant buds, dormant twigs, flowers, and fallen leaves collected from the ground (Table 1). The isolates were purified using single conidia methods on PDA and stored dry on filter paper at $-20^{\circ} \mathrm{C}$ in the culture collection of the Federal University of Paraná in Curitiba, Brazil. These isolates have been previously identified molecularly (Moreira et al. 2019) as $C$. nymphaeae $(n=109)$ and C. paranaense $(n=5)$ (Table 1$)$.

Discriminatory doses for mancozeb and thiophanate-methyl. All 114 isolates of the C. acutatum species complex were first tested by measuring mycelial growth using discriminatory doses of mancozeb (Dithane WP 80\% of mancozeb; Dow AgroSciences Industrial Ltda., Sao Paolo, Brazil) and thiophanate-methyl (Cercobin WP $70 \%$ of thiophanate-methyl; IHARABRAS S.A., Sorocaba, Brazil). The methodology of mycelial growth was chosen for the preliminary tests because it allows comparisons with previous studies (Cai et al. 2008; Ferreira et al. 2009; Kumar et al. 2007; Ling et al. 2010; Tam et al. 2008). Both products were suspended in sterile water, adjusted to $10,000 \mu \mathrm{g} \cdot \mathrm{ml}^{-1}$ for the stock solution, and diluted in potatodextrose-agar (PDA) $\left(40^{\circ} \mathrm{C}\right)$ after sterilization, resulting in one concentration for mancozeb $\left(1,000 \mu \mathrm{g} \cdot \mathrm{ml}^{-1}\right)$ and two concentrations for thiophanate-methyl $\left(1\right.$ and $\left.100 \mu \mathrm{g} \cdot \mathrm{ml}^{-1}\right)$.

Each isolate was grown on PDA at $25^{\circ} \mathrm{C}$ for 7 days. Mycelial disks (diameter, $3 \mathrm{~mm}$ ) were removed from the margins of the colonies and transferred to PDA amended with fungicide. Four replicates were used per isolate per concentration of active ingredient. Plates were kept at $25^{\circ} \mathrm{C}$ in the dark for 5 days, and mycelial growth of the isolates was measured daily on the orthogonal axes of the colonies. Each experiment was conducted twice.

The diameters of the colonies in the presence of different doses of fungicides were subtracted from the diameters of the colonies on the control plates (without fungicide) and the isolates from different parts of the apple tree (symptomatic leaves, dormant buds, dormant branches, flowers, and fallen leaves) were compared. Isolates from symptomatic leaves of the cultivars Gala and Eva were also compared. The mean diameters of the colonies and the differences in population sensitivity were calculated and then verified with the Welch $t$ test; results were considered significant at $P<0.05$ (R Core Team 2013).

EC50 values for mancozeb, thiophanate methyl, and azoxystrobin. A sample of isolates was selected based on their sporulation at the time of the experiment (Tables 2 and 3 ) and subjected to different concentrations of commercial formulations of mancozeb (Dithane WP 80\% of mancozeb; Dow AgroSciences Industrial Ltda.), thiophanate-methyl (Cercobin WP $70 \%$ of thiophanate-methyl; IHARABRAS S.A.), and azoxystrobin (Abound 22.4\% azoxystrobin; Syngenta Crop Protection, Greensboro, NC).

Mancozeb. The effective concentration value that inhibited 50\% of the pathogen development (EC50) of mancozeb was evaluated by mycelial growth and conidial germination. The fungicide was suspended in sterile water, adjusted to $10,000 \mu \mathrm{g} \cdot \mathrm{ml}^{-1}$ a.i. for the stock solution, and diluted in PDA and water agar (WA) for mycelial growth and conidial germination assays, respectively, after sterilization of the media. The concentrations of mancozeb for mycelial growth were $0,12.5,50,200,400,800$, and $1,600 \mu \mathrm{g} \cdot \mathrm{ml}^{-1}$; the concentrations of mancozeb for conidial germination were $0,0.03,0.1$, $0.3,1,3,10$, and $30 \mu \mathrm{g} \cdot \mathrm{ml}^{-1}$.

Mycelial growth experiments were conducted as the discriminatory dose experiments; however, for the EC50 assays, three replicates 
were used for each isolate and concentration. For the conidial germination assay, suspensions were adjusted to $104 \mathrm{conidia} / \mathrm{ml}^{-1}$. Aliquots of $40 \mu \mathrm{l}$ of each suspension were pipetted onto WA amended with fungicide and spread over the medium. Three Petri dishes (repetitions) were used per treatment and incubated at $25^{\circ} \mathrm{C}$ in the dark for $12 \mathrm{~h}$. To facilitate the evaluation, the germination process was stopped after $12 \mathrm{~h}$ by adding lactoglycerol to the culture medium containing each conidial suspension. The first 100 conidia found on each plate were evaluated using a light microscope at $40 \times$ magnification. The conidia were considered germinated if they had a germ tube equal to or longer than the conidium.

Thiophanate-methyl. Thiophanate-methyl EC50 was evaluated only by mycelial growth. The fungicide was suspended in sterile water, adjusted to $10,000 \mu \mathrm{g} \cdot \mathrm{ml}^{-1}$ a.i. for the stock solution, and then diluted in PDA after sterilization of the media. The concentrations of thiophanate-methyl for mycelial growth evaluation were $0,12.5$, $50,200,400,800$, and $1,600 \mu \mathrm{g} \cdot \mathrm{ml}^{-1}$. The experimental design and data collection were that same as those described for the mancozeb mycelial growth assays.

Azoxystrobin. Azoxystrobin EC50 was evaluated only by conidial germination. Azoxystrobin was diluted in sterile deionized water to prepare a stock solution of $388.4 \mu \mathrm{g} \cdot \mathrm{ml}^{-1}$ a.i. The concentrations of azoxystrobin evaluated ranged from 0.01 to $3 \mu \mathrm{g} \cdot \mathrm{ml}^{-1}$. In additional trials with some isolates, a greater concentration range ( 1 to $100 \mu \mathrm{g} \cdot \mathrm{ml}^{-1}$ ) was used. These concentration ranges were applied using the spiral gradient dilution method in WA (Forster et al. 2004). SHAM (at $100 \mu \mathrm{g} \cdot \mathrm{ml}^{-1}$ SHAM diluted in a 1:1 solution of acetone-methanol) was added to azoxystrobinamended WA.

The plates were divided into four sections, and $7 \mu l$ of a 103conidia/ml suspension was seeded in duplicate across the concentration gradient with a multichannel pipette. Two isolates were evaluated per plate, and two replicate plates were used (fungicide + SHAM or control).

Table 2. EC50 values for mancozeb for mycelial growth and germination, resistance factor (RF) for germination, and sensitivity classification for germination of Colletotrichum acutatum species complex isolates obtained from apples

\begin{tabular}{|c|c|c|c|c|c|c|}
\hline \multirow[b]{2}{*}{ Isolate } & \multirow[b]{2}{*}{ Species ${ }^{\mathbf{a}}$} & \multicolumn{2}{|c|}{$\operatorname{EC50}\left(\mu \mathrm{g} \cdot \mathrm{ml}^{-1}\right)^{b}$} & \multirow{2}{*}{$\underset{\text { germination }}{\mathbf{R F}}$} & \multirow{2}{*}{$\begin{array}{l}\text { Classification } \\
\text { germination }\end{array}$} & \multirow{2}{*}{$\begin{array}{c}\text { Mean BR lesion } \\
\text { diameter }(\mathrm{cm})\end{array}$} \\
\hline & & Mycelial growth & $\overline{\text { Germination }}$ & & & \\
\hline 181 & $\mathrm{Cn}$ & $>1,600.00$ & 1.97 & reference & $S$ & 0 \\
\hline 142 & $\mathrm{Cn}$ & $>1,600.00$ & 2.22 & 1.12 & S & 0 \\
\hline Col19 & $\mathrm{Cp}$ & $>1,600.00$ & 5.18 & 2.63 & LR & $<2$ \\
\hline 116 & $\mathrm{Cn}$ & $>1,600.00$ & 5.69 & 2.89 & LR & $-^{\mathrm{d}}$ \\
\hline 177 & $\mathrm{Cn}$ & $>1,600.00$ & 5.81 & 2.95 & LR & $<2$ \\
\hline 178 & $\mathrm{Cn}$ & 368.53 & 7.71 & 3.91 & LR & - \\
\hline 161 & $\mathrm{Cn}$ & $>1,600.00$ & 86.25 & 43.78 & HR & $>2$ \\
\hline 179 & $\mathrm{Cn}$ & $>1,600.00$ & 92.60 & 47.01 & HR & $>2$ \\
\hline
\end{tabular}

${ }^{\mathrm{a}} \mathrm{Cn}=$ C. nymphaeae. $\mathrm{Cp}=$ C. paranaense (Moreira et al. 2019).

${ }^{\mathrm{b}}$ Classification of isolates according to Ishii (2015). $\mathrm{HR}=$ highly resistant, $\mathrm{LR}=$ low resistance, $\mathrm{R}=$ resistant, $\mathrm{MR}=$ moderately resistant and $\mathrm{S}=$ sensitive. The $\mathrm{RF}$ for each isolate was calculated using the lowest EC50 isolate as a reference and dividing the EC50 value of the isolate by the EC50 value of the reference isolate. $\mathrm{HR}=\mathrm{RF}>20.0, \mathrm{R}=\mathrm{RF}$ between 10.1 and 20.0, $\mathrm{MR}=\mathrm{RF}$ between 5.1 and 10.0, $\mathrm{LR}=\mathrm{RF}$ between 1.6 and 5.0, and $\mathrm{S}=\mathrm{RF}$ between 0.0 and 1.5 .

${ }^{\mathrm{c}}$ EC50 $=$ effective concentration where growth was reduced by $50 \%$.

${ }^{\mathrm{d}}$ Dashes indicate not inoculated.

Table 3. Sensitivity classification of Colletotrichum acutatum species complex isolates from apples to thiophanate-methyl and azoxystrobin fungicides based on the EC50 values

\begin{tabular}{|c|c|c|c|c|c|c|c|}
\hline \multirow[b]{2}{*}{ Isolate } & \multirow[b]{2}{*}{ Species $^{\mathbf{a}}$} & \multicolumn{3}{|c|}{ Thiophanate-methyl } & \multicolumn{3}{|c|}{ Azoxystrobin } \\
\hline & & $\operatorname{EC50}\left(\mathrm{mg} \cdot \mathrm{ml}^{-1}\right)^{\mathbf{b}}$ & Classification $^{\mathrm{c}}$ & $\begin{array}{c}\text { Mean BR } \\
\text { lesion diameter }(\mathrm{cm})\end{array}$ & $\operatorname{EC50}\left(\mathrm{mg} \cdot \mathrm{ml}^{-1}\right)$ & Classification $^{\mathbf{d}}$ & $\begin{array}{c}\text { Mean BR lesion } \\
\text { diameter }(\mathrm{cm})\end{array}$ \\
\hline$\overline{c o l 19}$ & $\mathrm{Cp}$ & 17.68 & MR & $<2$ & 0.20 & $S$ & 0 \\
\hline 152 & $\mathrm{Cp}$ & 61.65 & MR & $<2$ & 0.30 & S & - \\
\hline 70 & $\mathrm{Cn}$ & 69.04 & MR & $--^{\mathrm{e}}$ & 0.22 & $S$ & - \\
\hline 120 & $\mathrm{Cn}$ & 137.32 & $\mathrm{R}$ & $>2$ & 0.39 & S & - \\
\hline 138 & $\mathrm{Cn}$ & 173.72 & $\mathrm{R}$ & $>2$ & 0.33 & S & - \\
\hline 176 & $\mathrm{Cn}$ & $>1,600.00$ & HR & - & 0.13 & $\mathrm{~S}$ & - \\
\hline 177 & $\mathrm{Cn}$ & $>1,600.00$ & HR & - & $>100.00$ & HR & $>2$ \\
\hline 178 & $\mathrm{Cn}$ & $>1,600.00$ & HR & - & 0.12 & $\mathrm{~S}$ & - \\
\hline 179 & $\mathrm{Cn}$ & $>1,600.00$ & HR & - & 0.08 & $S$ & - \\
\hline 181 & $\mathrm{Cn}$ & $>1,600.00$ & HR & $>2$ & 3.45 & $\mathrm{R}$ & $>2$ \\
\hline 122 & $\mathrm{Cn}$ & $>1,600.00$ & HR & - & 0.22 & S & - \\
\hline 126 & $\mathrm{Cn}$ & $>1,600.00$ & HR & - & 0.25 & $S$ & - \\
\hline 128 & $\mathrm{Cn}$ & $>1,600.00$ & HR & - & 0.40 & $S$ & - \\
\hline 134 & $\mathrm{Cn}$ & $>1,600.00$ & HR & - & 2.25 & S & - \\
\hline 159 & $\mathrm{Cn}$ & $>1,600.00$ & HR & - & 0.21 & S & - \\
\hline 161 & $\mathrm{Cn}$ & $>1,600.00$ & HR & $>2$ & 0.52 & $S$ & 0 \\
\hline 163 & $\mathrm{Cn}$ & $>1,600.00$ & HR & - & $>100.00$ & HR & $>2$ \\
\hline 173 & $\mathrm{Cn}$ & $>1,600.00$ & HR & - & 0.19 & S & - \\
\hline
\end{tabular}

${ }^{\mathrm{a}} \mathrm{Cn}=C$. nymphaeae $\mathrm{Cp}=C$. paranaense (Moreira et al. 2019).

${ }^{\mathrm{b}} \mathrm{EC} 50=$ effective concentration where growth was reduced by $50 \%$.

${ }^{\mathrm{c}}$ Classification of isolates according to Chung et al. (2006). $\mathrm{HR}=$ highly resistant, $\mathrm{R}=$ resistant, $\mathrm{MR}=$ moderately resistant, and $\mathrm{S}=$ sensitive. $\mathrm{HR}=\mathrm{EC} 50>500$ $\mu \mathrm{g} \cdot \mathrm{ml}^{-1}, \mathrm{R}=$ EC50 between 100 and $500 \mu \mathrm{g} \cdot \mathrm{ml}^{-1}, \mathrm{MR}=\mathrm{EC} 50$ between 10 and $100 \mu \mathrm{g} \cdot \mathrm{ml}^{-1}, \mathrm{~S}=\mathrm{EC} 50<10 \mu \mathrm{g} \cdot \mathrm{ml}^{-1}$.

${ }^{\mathrm{d}}$ Classification of isolates according to Forcelini et al. (2016). $\mathrm{HR}=$ highly resistant, $\mathrm{R}=$ resistant, and $\mathrm{S}=$ sensitive. $\mathrm{HR}=\mathrm{EC} 50>100 \mu \mathrm{g} \cdot \mathrm{ml}^{-1}, \mathrm{R}=\mathrm{EC} 50 \mathrm{between}$ 3 and $100 \mu \mathrm{g} \cdot \mathrm{ml}^{-1}, \mathrm{~S}=\mathrm{EC} 50<3 \mu \mathrm{g} \cdot \mathrm{ml}^{-1}$.

e Dashes indicate that the isolate was not used in fruit inoculations. 
EC50 calculation and sensitivity classification. For each concentration of mancozeb and thiophanate-methyl, the inhibition of mycelial growth (I) and/or the inhibition of the germination of each isolate was calculated as $\mathrm{I}=(\mathrm{Ct}-\mathrm{Cx}) / \mathrm{Ct} \times 100$, where $\mathrm{Ct}$ is the mean mycelial growth or mean germination of the control (without fungicide) and $\mathrm{Cx}$ is the mean mycelial growth or mean germination of each isolate. The effective concentration value that inhibited $50 \%$ of the pathogen development (EC50) for each isolate was obtained using a linear regression between the percentage of inhibition of spore germination calculated relative to the control (i.e., without fungicide) that represented $0 \%$ inhibition and the corresponding $\log 10$ concentrations of the fungicide. The EC50 values were subjected to an analysis of variance $(\mathrm{F} \leq 0.05)$ ( $\mathrm{R}$ Core Team 2013). For azoxystrobin, the point within the fungicide gradient where conidia germination was reduced by $50 \%$ compared with the control plates was marked, and the distance to the plate center was used to determine the EC50 values using the Spiral Gradient Endpoint Software (Spiral Biotech, Inc., Norwood, MA).

For mancozeb (conidial germination), the isolates were classified according to Ishii (2015). The resistance factor (RF) for each isolate was calculated using the lowest EC50 isolate as a reference by dividing the EC50 value of the isolate by the EC50 value of the reference isolate. Isolates with RF $>20.0$ were considered highly resistant, those with RF between 10.1 and 20.0 were considered resistant, those with RF between 5.1 and 10.0 were considered moderately resistant, those with RF between 1.6 and 5.0 were considered to have low resistance, and those with RF between 0.0 and 1.5 were considered sensitive.

For thiophanate-methyl, the isolates were classified according to Chung et al. (2006). Isolates with EC50 $>500 \mu \mathrm{g} \cdot \mathrm{ml}^{-1}$ were considered highly resistant, those with EC50 between 100 and $500 \mu \mathrm{g} \cdot \mathrm{ml}^{-1}$ were considered resistant, those with EC50 between 10 and $100 \mu \mathrm{g} \cdot \mathrm{ml}^{-1}$ were considered moderately resistant, and those with EC50 $<10 \mu \mathrm{g} \cdot \mathrm{ml}^{-1}$ were considered sensitive.

For azoxystrobin, the isolates were classified according to Forcelini et al. (2016). Isolates with EC50 >100 $\mu \mathrm{g} \cdot \mathrm{ml}^{-1}$ were considered highly resistant, those with EC50 between 3 and $100 \mu \mathrm{g} \cdot \mathrm{ml}^{-1}$ were considered resistant, and those with EC50 $<3 \mu \mathrm{g} \cdot \mathrm{ml}^{-1}$ were considered sensitive.

Analysis of $\beta$-tubulin and cytochrome $b$ partial gene sequences. Fungal colonies of two highly resistant, two resistant, and two moderately resistant isolates to thiophanate-methyl and of two highly resistant, one resistant, and one isolate sensitive to azoxystrobin were grown on PDA for 7 days. Then, mycelia were harvested and DNA was extracted using the FastDNA Kit (MP Biomedicals, Solon, $\mathrm{OH}$ ).

A partial region of the $\beta$-tubulin gene was amplified by PCR using the primers TB2L and TB2R (Peres et al. 2004). The reaction conditions were $1.5 \mu \mathrm{l}$ DNA $\left(25 \mathrm{ng} \cdot \mu \mathrm{l}^{-1}\right), 5 \mu \mathrm{l}$ buffer $5 \times, 0.2 \mu \mathrm{l}$ Taq polymerase, $1 \mu l$ primer (10 mM), $0.5 \mu l$ dNTP $(10 \mathrm{mM}), 1.5 \mu \mathrm{l} \mathrm{MgCl}_{2}$ $(25 \mathrm{mM})$, and $14.3 \mu \mathrm{l}$ water in a final volume of $25 \mu \mathrm{l}$ of the reaction. The amplifications were performed in an Eppendorf thermal cycler (Bio-Rad) under the following conditions: initial denaturation at $95^{\circ} \mathrm{C}$ for $3 \mathrm{~min} ; 34$ cycles of $1 \mathrm{~min}$ at $95^{\circ} \mathrm{C} ; 1 \mathrm{~min}$ at $58^{\circ} \mathrm{C} ; 1 \mathrm{~min}$ at $72^{\circ} \mathrm{C}$; and a final extension of $5 \mathrm{~min}$ at $72^{\circ} \mathrm{C}$.

A partial region of cytochrome $b$ was amplified by PCR using the primers C.gramcytb-bf1 5'-GAAGAGGTATGTACTACGGTTCA TATAG-3' and C.gramcytb-br1 5'-TAGCAGCTGGAGTTTGCA TAG-3' (Forcelini et al. 2016). The reaction conditions were $1 \mu 1$ DNA $\left(25 \mathrm{ng} \cdot \mu \mathrm{l}^{-1}\right), 5 \mu \mathrm{l}$ buffer $5 \times, 0.2 \mu \mathrm{l}$ Taq polymerase, $0.5 \mu \mathrm{l}$ primer $(10 \mathrm{mM}), 0.5 \mu \mathrm{l}$ de dNTP $(10 \mathrm{mM}), 1.5 \mu \mathrm{l} \mathrm{MgCl}_{2}$ $(25 \mathrm{mM})$, and $15.8 \mu \mathrm{l}$ water in a final volume of $25 \mu \lambda$ of reaction. Amplifications were performed in an Eppendorf thermal cycler (BioRad) with the following conditions: initial denaturation $95^{\circ} \mathrm{C}$ for $3 \mathrm{~min} ; 34$ cycles from $40 \mathrm{~s}$ to $95^{\circ} \mathrm{C} ; 50 \mathrm{~s}$ to $60^{\circ} \mathrm{C} ; 1 \mathrm{~min}$ to $72^{\circ} \mathrm{C}$; and a final extension of $5 \mathrm{~min}$ to $72^{\circ} \mathrm{C}$.

The amplicons ( $400 \mathrm{pb}$ for $\beta$-tubulin and $300 \mathrm{pb}$ for cytochrome $\mathrm{b}$ ) were visualized in $1 \%$ agarose gel with $1 \times$ TAE buffer $(0.04 \mathrm{M}$ Trisacetate, 0.0001 M EDTA buffer) plus GelRed (Biotium, Fremont, $\mathrm{CA}$ ). The PCR products were purified and sequenced (Genewiz
Inc., Plainfield, NJ). The forward and reverse sequences generated were assembled using BioEdit software (http://www.mbio.ncsu. edu/bioedit/bioedit.html). Reference gene strains of Colletotrichum spp. available on GenBank were added to the dataset. Sequences with the mutation at codon 198 (FJ476048.1), at codon 200 (FJ476051.1), and without a mutation (XM_00760127.1) in the $\beta$-tubulin gene (Chung at al. 2006; Wong et al. 2008; Young et al. 2010), as well as a sequence without mutation (KR349346.1) in the cytochrome $b$ gene, were chosen. These sequences were aligned with the obtained sequences and edited with MEGA v.5.2 software (Tamura et al. 2011).

Severity of symptoms caused by $C$. acutatum species complex isolates inoculated in apple fruit treated with mancozeb, thiophanate-methyl, and azoxystrobin. Gala fruit were surfacedisinfested ( $1 \mathrm{~min}$ in $70 \%$ alcohol, $1 \mathrm{~min}$ in $2 \%$ sodium hypochlorite, and washed three times in sterile distilled water). Then, they were wounded (depth, $0.5 \mathrm{~cm}$ ) and separately treated with fungicides (by immersion of the fruits in the fungicide suspension) at the field label rates $\left(1,600 \mu \mathrm{g} \cdot \mathrm{ml}^{-1}\right.$ for mancozeb; $500 \mu \mathrm{g} \cdot \mathrm{ml}^{-1}$ for thiophanate-methyl; and $150 \mu \mathrm{g} \cdot \mathrm{ml}^{-1}$ for azoxystrobin). Fruit were inoculated after $24 \mathrm{~h}$ with $40 \mu \mathrm{l}$ of suspensions adjusted to $104 \mathrm{con}$ $\mathrm{idia} / \mathrm{ml}^{-1}$. For the inoculations, two isolates belonging to each fungicide sensitivity class were chosen arbitrarily according to the EC50 by the conidia germination test (sensitive, low resistance, and highly resistant for mancozeb; moderately resistant, resistant, and highly resistant for thiophanate-methyl; and sensitive, resistant, and highly resistant for azoxystrobin). Fruit treated with water and inoculated with conidial suspensions of the same isolates were used as controls. The fruit were incubated at $25^{\circ} \mathrm{C}$ during a 12 -h photoperiod. The severity of symptoms was recorded after 7 days of incubation by measuring the lesion diameter of three fruit per fungicide per isolate, and each fruit was considered a repetition. Each experiment was conducted twice.

\section{Results}

Discriminatory doses for mancozeb and thiophanate-methyl. For mancozeb, the diameters of the colonies were significantly larger for isolates collected from symptomatic leaves when compared with the diameters of the colonies of the isolates collected from other parts of the plant. For thiophanate-methyl $\left(1 \mu \mathrm{g} \cdot \mathrm{ml}^{-1}\right)$, the diameters of the colonies were significantly larger for isolates collected from leaves on the ground when compared with the diameters of the colonies of the isolates collected from other parts of the plant. For thiophanate-methyl $\left(100 \mu \mathrm{g} \cdot \mathrm{ml}^{-1}\right)$, the diameters of the colonies were significantly larger for isolates collected from leaves on the ground when compared with the diameters of the colonies of the isolates collected from flowers and dormant twigs (Table 4).

Isolates recovered from Eva and Gala cultivars had significant differences in their colony diameters. At $1,000 \mu \mathrm{g} \cdot \mathrm{ml}^{-1}$ of mancozeb, the average colony diameters for isolates obtained from Eva and Gala were 1.315 and $1.804 \mathrm{~cm}$, respectively $(P=0.0001)$. At $1 \mu \mathrm{g} \cdot \mathrm{ml}^{-1}$ of thiophanate-methyl, the average colony diameters of isolates obtained from Eva and Gala were 2.577 and $3.318 \mathrm{~cm}$, respectively $(P=0.0001)$. At $100 \mu \mathrm{g} \cdot \mathrm{ml}^{-1}$ of thiophanate-methyl, the average colony diameters obtained for isolates from Eva and Gala were 1.817 and $2.212 \mathrm{~cm}$, respectively $(P=0.012)$ (Table 5).

EC50 values for mancozeb, thiophanate methyl, and azoxystrobin. EC50 values for mancozeb fungicide were different between mycelial growth and conidia germination tests. The frequencies of resistance of $C$. acutatum to mancozeb based on EC50 values obtained by conidial germination were as follows: $25 \%$ highly resistant isolates; $50 \%$ low-resistance isolates; and 25\% sensitive isolates (Table 2). The frequencies of resistance of $C$. acutatum to thiophanate-methyl based on EC50 values obtained by mycelial growth at different concentrations were as follows: $72.2 \%$ highly resistant isolates; $11.1 \%$ resistant isolates; and $16.7 \%$ moderately resistant isolates (Table 3). The frequencies of resistance of $C$. acutatum to azoxystrobin based on EC50 values obtained by conidial germination at different concentrations were as follows: $11.1 \%$ highly resistant isolates; $5.6 \%$ resistant isolates; and $83.3 \%$ sensitive isolates (Table 3 ). 
Analysis of $\beta$-tubulin and cytochrome $b$ partial gene sequences. Nucleotide sequencing of a portion of the $\beta$-tubulin gene of six $C$. acutatum isolates with different sensitivity responses to thiophanate-methyl did not show any substitutions at codons 177, 198, and 200 (Fig. 1). Despite some differences in nucleotide sequences among the isolates (data not shown), there were no substitutions of the amino acids.

Nucleotide sequencing of a portion of the cytochrome $b$ gene of four C. acutatum isolates with different sensitivity responses to azoxystrobin did not show any substitutions at codons 129, 137, and 143 (Fig. 2). Nucleotide sequences obtained for all isolates used in this study were deposited in the GenBank database (accession numbers).

Severity of symptoms caused by $C$. acutatum isolates inoculated in apple fruit treated with mancozeb, thiophanate-methyl, and azoxystrobin. Seven days after inoculation, isolates classified

Table 4. Comparisons of colony diameters of Colletotrichum acutatum species complex isolates collected from different parts of the apple tree and plated in fungicide-amended media ${ }^{a}$

\begin{tabular}{|c|c|c|c|c|c|c|}
\hline \multirow[b]{2}{*}{ Parts of the plant } & \multirow[b]{2}{*}{$\mathbf{n}$} & \multicolumn{5}{|c|}{$\begin{array}{l}\text { Mean colony diameter values } \\
(\mathrm{cm}) \text { and } P \text { value }\end{array}$} \\
\hline & & DB & DT & FL & LG & SL \\
\hline \multicolumn{7}{|c|}{ Mancozeb $\left(1,000 \mathrm{mg} \cdot \mathrm{ml}^{-1}\right)$} \\
\hline DB & 17 & 0.971 & 0.189 & 0.415 & 0.961 & 0.045 \\
\hline DT & 21 & & 0.770 & 0.851 & 0.158 & 0.002 \\
\hline FL & 6 & & & 0.803 & 0.385 & 0.015 \\
\hline LG & 21 & & & & 0.980 & 0.046 \\
\hline SL & 25 & & & & & 1.421 \\
\hline \multicolumn{7}{|c|}{ Thiophanate-methyl $\left(1 \mathrm{mg} \cdot \mathrm{ml}^{-1}\right)$} \\
\hline DB & 17 & 1.468 & 0.000 & 0.261 & 0.015 & 0.001 \\
\hline DT & 20 & & 0.665 & 0.125 & 0.000 & 0.709 \\
\hline FL & 6 & & & 1.123 & 0.010 & 0.173 \\
\hline LG & 21 & & & & 2.033 & 0.000 \\
\hline SL & 19 & & & & & 0.724 \\
\hline \multicolumn{7}{|c|}{$\begin{array}{l}\text { Thiophanate-methyl } \\
\left(100 \mathrm{mg} \cdot \mathrm{ml}^{-1}\right)\end{array}$} \\
\hline $\mathrm{DB}$ & 24 & 1.139 & 0.088 & 0.079 & 0.173 & 0.641 \\
\hline DT & 22 & & 0.742 & 0.880 & 0.001 & 0.046 \\
\hline FL & 6 & & & 0.727 & 0.001 & 0.041 \\
\hline LG & 23 & & & & 1.553 & 0.442 \\
\hline SL & 28 & & & & & 1.296 \\
\hline \multicolumn{7}{|c|}{$\begin{array}{l}\text { a } L G=\text { leaves on the ground during the winter period, SL = symptomatic } \\
\text { leaves, FL = flowers, DB = dormant buds, DT = dormant twig. } \\
\text { b The mean colony diameter values are in bold. The diameter of the colonies in } \\
\text { the presence of different doses of fungicides were subtracted from the diam- } \\
\text { eters of the colonies in the control plates (without fungicide). } \\
\text { c } P \text { values were obtained using the Welch } t \text { test }\end{array}$} \\
\hline
\end{tabular}

Table 5. Comparisons of colony diameters of Colletotrichum acutatum species complex isolates collected from symptomatic leaves from Eva and Gala cultivars and plated in fungicide-amended media

\begin{tabular}{|c|c|c|c|}
\hline \multirow[b]{2}{*}{ Cultivar } & \multirow[b]{2}{*}{$\mathbf{n}$} & \multicolumn{2}{|c|}{$\begin{array}{c}\text { Mean colony } \\
\text { diameter values } \\
(\mathrm{cm}) \text { and } P \text { value } \\
\text { b }\end{array}$} \\
\hline & & Eva & Gala \\
\hline \multicolumn{4}{|c|}{ Mancozeb $\left(1,000 \mathrm{mg} \cdot \mathrm{ml}^{-1}\right)$} \\
\hline Eva & 16 & 1.315 & 0.000 \\
\hline Gala & 30 & & 1.804 \\
\hline \multicolumn{4}{|c|}{ Thiophanate-methyl $\left(1 \mathrm{mg} \cdot \mathrm{ml}^{-1}\right)$} \\
\hline Eva & 17 & 2.577 & 0.000 \\
\hline Gala & 23 & & 3.318 \\
\hline \multicolumn{4}{|c|}{ Thiophanate-methyl $\left(100 \mathrm{mg} \cdot \mathrm{ml}^{-1}\right)$} \\
\hline Eva & 18 & 1.817 & 0.012 \\
\hline Gala & 33 & & 2.212 \\
\hline
\end{tabular}

a The mean colony diameter values are in bold. The diameters of the colonies in the presence of different doses of fungicides were subtracted from the diameters of the colonies on the control plates (without fungicide).

${ }^{\mathrm{b}} P$ values were obtained using the Welch $t$ test. as sensitive or as having low resistance to mancozeb caused no BR symptoms on wounded fruit treated with the concentration of mancozeb used in the field, but isolates classified as highly resistant caused BR lesions (average diameter, $2 \mathrm{~cm}$ ) (Fig. 3). Isolates classified as moderately resistant to thiophanate-methyl also caused BR lesions with an average diameter of $2 \mathrm{~cm}$ on wounded fruit treated with the concentration of thiophanate-methyl used in the field, whereas isolates classified as resistant and highly resistant caused lesions with an average diameter of $3 \mathrm{~cm}$ (Fig. 4). Isolates classified as sensitive caused no BR symptoms on wounded fruit treated with the concentration of azoxystrobin used in the field, but isolates classified as resistant and highly resistant caused BR lesions with an average diameter of $2 \mathrm{~cm}$ (Fig. 5).

\section{Discussion}

The $C$. acutatum isolates used in this study showed different sensitivity levels to mancozeb, thiophanate-methyl, and azoxystrobin. Sensitivity varied among isolates from the different parts of the plant and between cultivars; furthermore, for the three fungicides, isolates classified as highly resistant were found. The reduced sensitivity of the isolates to the main fungicides used to control GLS could be a reason for the poor disease control observed by apple producers in Paraná State. However, several other factors could be involved, such as increased pathogen aggressiveness, favorable environment conditions, and poor spray coverage.

Isolates collected from symptomatic leaves had the largest colony diameters in the presence of mancozeb compared with isolates from other parts of the plant, and isolates collected from leaves on the ground had the largest diameters in the presence of thiophanatemethyl compared with isolates from other parts of the plant. The higher frequency of resistance of Colletotrichum isolates collected from leaves in general may be related to the higher frequency of application of fungicides from leaf emergence to leaf fall compared with the shorter life of flowers, buds, and twigs. Therefore, selection pressure for resistant isolates may be higher on the leaves.

Hamada and May De Mio (2017) showed that leaves on the ground are a main source of primary inoculum in apple orchards, and that most of these isolates were pathogenic to fruit and leaves. In the present study, the average colony diameters of isolates obtained from leaves on the ground were significantly larger than those from other parts of the plant for thiophanate-methyl. These results reinforced that the rapid decomposition of leaves on the ground is important for reducing the amount of initial inoculum during each cycle of the crop and, consequently, reducing the population of resistant isolates.

The Eva cultivar was released in 1999 (IAPAR 2008) and has been considered GLS-resistant (Furlan 2010), but symptoms of this cultivar have been increasing in Paraná State since 2010. Isolates from 'Gala' had larger colony diameters in medium amended with the fungicides tested during this study than those from 'Eva'. One explanation could be that the Gala cultivar, known to be highly susceptible, is more frequently sprayed with fungicides; therefore, the

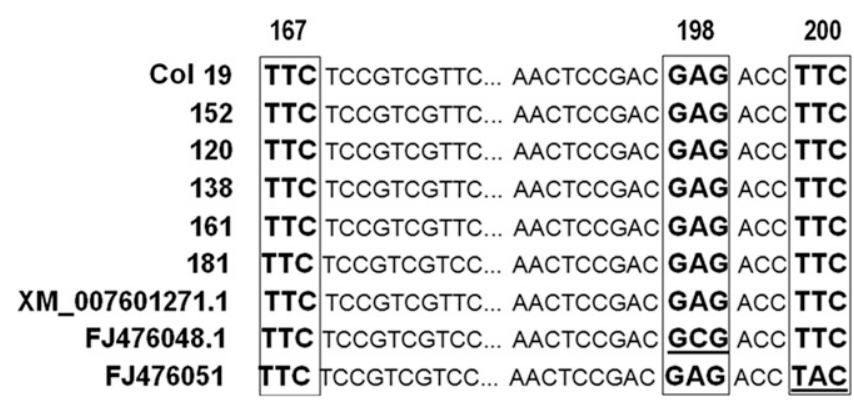

Fig. 1. Partial nucleotide sequences of $\beta$-tubulin of Colletotrichum acutatum isolates from apple groves with different sensitivity profiles to thiophanate-methyl. Nucleotides encoding amino acids 167 (phenylalanine), 198 (glutamic acid), and 200 (phenylalanine) are boxed. 


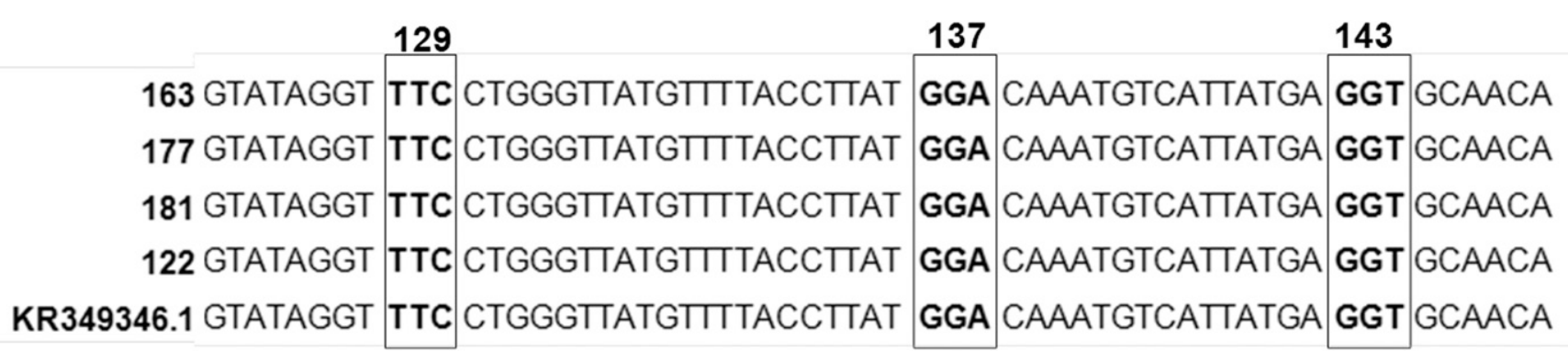

Fig. 2. Partial nucleotide sequences of cytochrome b of Colletotrichum acutatum isolates from apple groves with different sensitivity profiles to azoxystrobin. Nucleotides encoding amino acids 129 (phenylalanine), 137 (glycine), and 143 (glycine) are boxed.

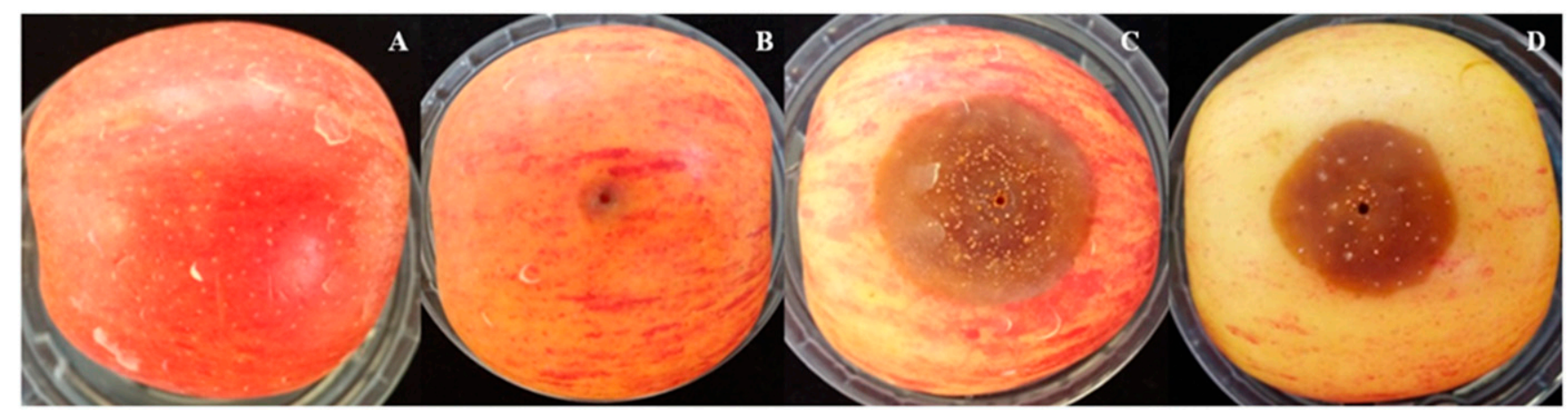

Fig. 3. A, Symptoms of bitter rot 7 days after inoculation of wounded 'Gala' fruit treated with mancozeb at $1600 \mu \mathrm{g} \cdot \mathrm{ml}^{-1}$ and subsequently inoculated with a conidial suspension of a sensitive isolate, $\mathbf{B}$, low-resistance isolate, $\mathbf{C}$, highly resistant isolate, and $\mathbf{D}$, control fruit without fungicide.

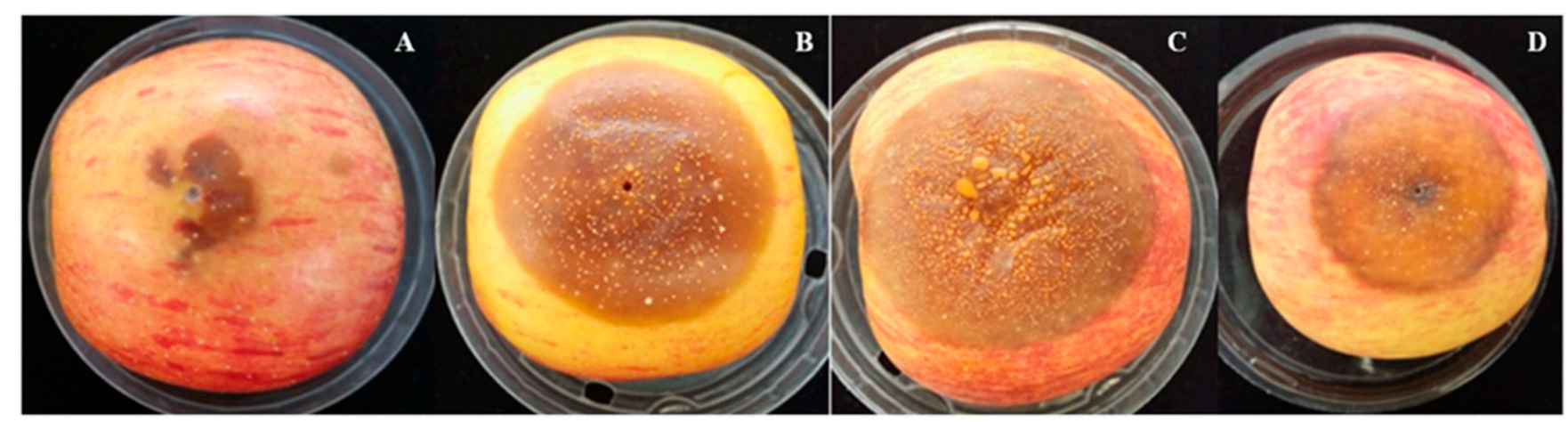

Fig. 4. A, Symptoms of bitter rot 7 days after inoculation of wounded 'Gala' fruit treated with thiophanate-methyl at $500 \mu \mathrm{g} \cdot \mathrm{ml}^{-1}$ and subsequently inoculated with a conidial suspension of moderately resistant isolate. $\mathbf{B}$, resistant isolate, $\mathbf{C}$, highly resistant isolate, and $\mathbf{D}$, control fruit without fungicide.

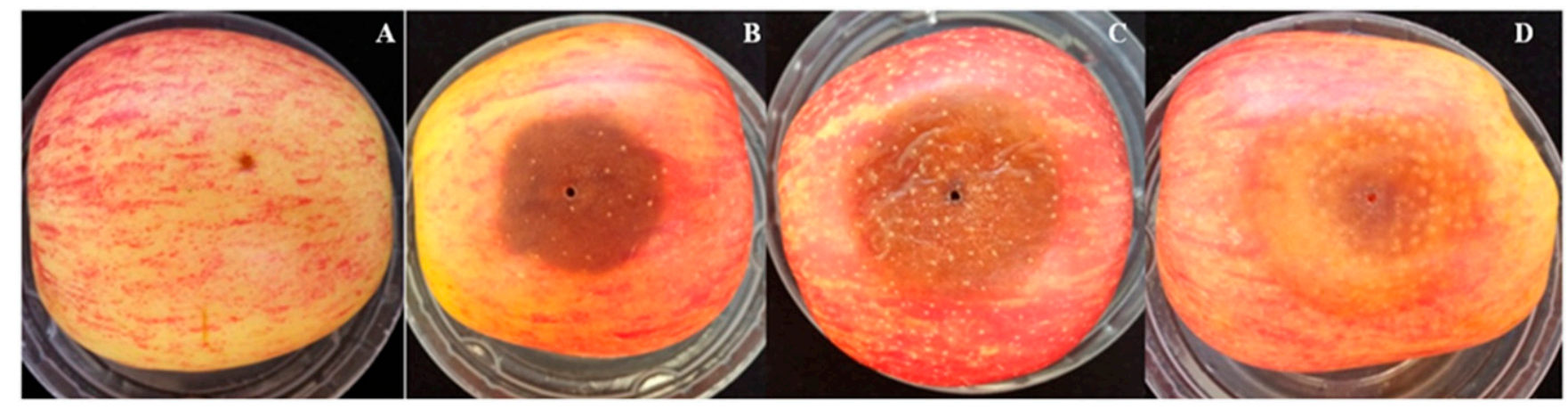

Fig. 5. A, Symptoms of bitter rot 7 days after inoculation of wounded 'Gala' fruit treated with azoxystrobin at $1600 \mu \mathrm{g} \cdot \mathrm{ml}^{-1}$ and subsequently inoculated with a conidial suspension of sensitive isolate, $\mathbf{B}$, resistant isolate, $\mathbf{C}$, highly resistant isolate, and $\mathbf{D}$, control fruit without fungicide. 
Colletotrichum isolates present in this cultivar were exposed to higher fungicide selection pressure.

Mancozeb is one of the most commonly applied fungicides for the control of GLS in Brazil (Katsurayama and Bonetti 2009), and it is considered to present a low risk for the development of pathogen resistance because of its protective characteristics and broad spectrum of action (Brent and Hollomon 2007). However, the resistance of Colletotrichum spp. to mancozeb has been reported for C. gloeosporioides in citrus (Ling et al. 2010), for C. gloeosporioides and C. acutatum in rubber tree (Cai et al. 2008), for C. gloeosporioides in postharvest apple fruit (Tam et al. 2008), for C. gloeosporioides in coffee (Ferreira et al. 2009), and for C. gloeosporioides in mango (Kumar et al. 2007).

Mancozeb resistance detected in the aforementioned studies was determined by mycelial growth assays; however, this method might not be adequate for determining resistance to mancozeb, and conidial germination assays may be more appropriate because of the multisite mode of action (Gullino et al. 2010; Ishii 2015). In our study, the EC50 for mancozeb varied from 368.53 to $>1,600 \mu \mathrm{g} \cdot \mathrm{ml}^{-1}$ when using mycelium growth; however, for conidial germination, values varied from 1.97 to $92.6 \mu \mathrm{g} \cdot \mathrm{ml}^{-1}$. Munir et al. (2016) assessed the sensitivity of Colletotrichum species to captan, another multisite fungicide, and also obtained higher EC50 values (36.88 to $558.33 \mu \mathrm{g} \cdot \mathrm{ml}^{-1}$ ) for mycelium growth than for spore germination $\left(0.11\right.$ to $\left.0.51 \mu \mathrm{g} \cdot \mathrm{ml}^{-1}\right)$. The results of these two studies showed that there is a significant difference in the determination of EC50 values when using different methods, and that the conidial germination method may be more appropriate for determining resistance factors of Colletotrichum isolates to mancozeb. Future efforts are needed to evaluate a large population from all Brazilian production regions using this method and to validate this in vitro resistance relative to practical resistance using field experiments.

Studies have not been performed to understand the resistance mechanism to mancozeb, but one potential mechanism could be based on detoxification of the active fungicide (Gullino et al. 2010). This mechanism has been described for several different fungicides and various pathogens, including the multisite fungicide captan in Botrytis cinerea (Barak and Edgington 1984). It has also been suggested that the mechanism of resistance may be caused by overproduction of thiols, which detoxify fungicides (Barak and Edgington 1984). Investigations of the occurrence of this resistance mechanism in the isolates of Colletotrichum from apple with reduced sensitivity to mancozeb should be performed in the future.

Isolates used in this study grew in thiophanate-methyl at $100 \mu \mathrm{g} \cdot \mathrm{ml}^{-1}$ and were mostly classified as resistant or highly resistant. As reported previously, species belonging to $C$. acutatum have natural reduced sensitivity to methyl benzimidazole carbamates fungicides (Chung et al. 2006; Hamada et al. 2009; Peres et al. 2004); however, in some cases, despite the reduced sensitivity of the pathogen in vitro, these fungicides are still able to control disease in the field. In our study, field rates of thiophanate-methyl failed to control BR on apple fruit inoculated with isolates classified as resistant or highly resistant; however, isolates classified as moderately resistant (EC50 between 10 and $100 \mu \mathrm{g} \cdot \mathrm{ml}^{-1}$ ) seem to develop smaller lesions when treated with this fungicide. These results corroborate those of previous studies that indicated that despite reduced sensitivity in vitro, this fungicide might still provide field control. Although in the present study the same doses of fungicide used in the field were used for the sensitivity tests of fruits, applications of fungicides in the field can be influenced by several factors, such as environmental conditions and spray equipment, and it is unknown whether moderate resistant isolates would be controlled as well under field conditions.

Mutations that confer MBC resistance have been detected in the C. gloeosporioides species complex from different crops worldwide (Chung et al. 2010; Peres et al. 2004; Wong et al. 2008; Young et al. 2010) and in C. acutatum from strawberries and grapevines (Chung et al. 2006). None of the common mutations that confer resistance to thiophanate-methyl was observed in the $\beta$-tubulin gene for any isolates tested during the present study. This suggested that low sensitivity to thiophanate-methyl found in isolates from the present study may be governed by other factors. De Waard (1997) and Del Sorbo et al. (1997) reported that ATP-binding cassette transporter systems can have a role in multidrug resistance in filamentous fungi. Therefore, factors other than mutation of the $\beta$-tubulin gene, such as transporter systems, might have a role in the low sensitivity to benzimidazoles in C. acutatum.

Resistant and highly resistant azoxystrobin isolates were found in the $C$. acutatum population tested during this study. The first report of QoI resistance in C. acutatum involved strawberry (Forcelini et al. 2016), and isolates contained either G143A or F129L amino acid substitutions in the cytochrome b gene. Recently, the G143A mutation, which confers resistance to QoI fungicides, was detected in a population of the $C$. gloeosporioides species complex in Japan. According to the authors (Yokosawa et al. 2017), those isolates grew in $100 \mu \mathrm{g} \cdot \mathrm{ml}^{-1}$ of azoxystrobin. In this study, the common mutations related to resistance to QoIs in the cytochrome b gene (G143A, F129L, and G137R) were not found in C. acutatum isolates classified as resistant. Investigations of the occurrence of possible mutations in other genomic regions for both fungicides are challenges for future research. In our study, field rates of azoxystrobin failed to control BR on apple fruit inoculated with isolates classified as resistant or highly resistant, but the disease was controlled when sensitive isolates were inoculated. It is noteworthy to mention that even though azoxystrobin is not registered for apples because of phytotoxicity in some cultivars, other QoI fungicides such as pyraclostrobin are commonly used. In this study, we used azoxystrobin in our assays as a representative of the QoI fungicides group because it was readily available and because cross-resistance and sensitivity among the QoI fungicides are well known.

The fungicide groups tested in this study are the main ones used for the management of GLS in apple in Brazil, and there have been several reports by producers of difficulties controlling the disease. This anecdotal evidence agrees with the results of this research. Therefore, it is important to continue periodic monitoring to verify the frequency of resistant isolates in populations in different producing regions because populations of pathogens adapt to different management conditions that may increase or decrease population resistance (Brent and Hollomon 2007). Additionally, the use of fungicides with different modes of action as well as reducing the primary inoculum in the orchard, which are mainly associated with dormant buds, dormant twigs, apple trees, and fallen leaves during the winter, are recommended (Hamada and May De Mio 2017). Finally, the identification of other effective fungicides with different modes of action for GLS control is urgently needed.

\section{Literature Cited}

Agrofit. Sistemas de agrotóxicos fitossanitários (Phytosanitary pesticide systems). $<$ http://extranet.agricultura.gov.br/agrofit_cons/principal_agrofit_cons $>20$ March 2019.

Alaniz, S., Hernandez, L., Damasco, D., and Mondino, P. 2012. First report of Colletotrichum acutatum and $C$. fragariae causing bitter rot of apple in Uruguay. Plant Dis. 96:458.

Avila-Adame, C., Olaya, G., and Koller, W. 2003. Characterization of Colletotrichum graminicola isolates resistant to strobilurin related Qoi fungicides. Plant Dis. 87:1426-1432.

Barak, E., and Edgington, L. V. 1984. Cross resistance of Botrytis cinerea to captan, thiram, chlorothalonil and related fungicides. Can. J. Plant Pathol. 6: 318-320.

Bartlett, D. W., Clough, J. M., Godwin, J. R., Hall, A. A., Hamer, M., and ParrDobrzansk, B. 2012. The strobilurin fungicides. Pest manage. Sci. 58: 649-662.

Bonetti, J. I. S., Becker, W. F., and Katsurayama, Y. 2004. Sistema de previsão da mancha-foliar-da-gala em macieira, cultivar gala. Agropecu. Catarin. 17:64-67.

Bragança, C. A. D., Damm, U., Baroncelli, R., Massola Júnior, N. S., and Crous, P. W. 2016. Species of the Colletotrichum acutatum complex associated with anthracnose diseases of fruit in Brazil. Fungal Biol. 120:547-561.

Brent, K. J., and Hollomon, D. W. 2007. Fungicide resistance in crop pathogens: How can it be managed. Brussels: Fungicide Resistance Action Committee, Brussels, Belgium

Cai, Z., Li, J., Wang, J., Zhang, C., He, M., and He, L. 2008. Sensitivity test of Colletotrichum gloeosporioides and Colletotrichum acutatum isolate from rubber to the fungicides. Yunnan Nong Ye Da Xue Xue Bao 23:787-790.

Cannon, P. F., Damm, U., Johnston, P. R., and Weir, B. S. 2012. Colletotrichum current status and future directions. Stud. Mycol. 73:181-213. 
Chung, W. H., Chung, W. C., Peng, M. T., Yang, H. R., and Huang, J. W. 2010. Specific detection of benzimidazole resistance in Colletotrichum gloeosporioides from fruit crops by PCR-RFLP. N. Biotechnol. 27:17-24.

Chung, W. H., Ishii, H., Nishimura, K., Fukaya, M., Yano, K., and Kajitani, Y. 2006. Fungicide sensitivity and phylogenetic relationship of anthracnose fungi isolated from various fruit crops in Japan. Plant Dis. 90:506-512.

de Waard, M. A. 1997. Significance of ABC transporters in fungicide sensitivity and resistance. Pestic. Sci. 51:271-275.

Del Sorbo, G., Andrade, A. C., Van Nistelrooy, J. A. L., Balzi, E., and de Waard, M. A. 1997. Multidrug resistance in Aspergillus nidulans involves novel ATPbinding cassette transporters. Mol. Gen. Genet. 254:417-426.

Denardi, F., Berton, O., and Spengler, M. M. 2003. Resistência genética à podridão amarga em maçãs, determinadas pela taxa de desenvolvimento da doença em frutos com e sem ferimentos. Rev. Bras. Frutic. 25:494-497.

Ferreira, J. B., Abreu, M. S., Pereira, I. S., Fernandes, K. D., and Pereira, R. B. 2009. Sensibilidade de Colletotrichum gloeosporioides (Mancha Manteigosa do Cafeeiro) a diferentes concentrações de fungicidas. Cienc. Agrotec. 33 (spe):2052-2058

Forcelini, B. B., Seijo, T. E., Amiri, A., and Peres, N. A. 2016. Resistance in strawberry isolates of Colletotrichum acutatum from Florida to Quinoneoutside inhibitor fungicides. Plant Dis. 100:2050-2056.

Förster, H., Kanetis, L., and Adaskaveg, J. E. 2004. Spiral gradient dilution, a rapid method for determining growth responses and 50\% effective concentration values in fungus-fungicide interactions. Phytopathology 94:163-170.

FRAC. 2013. Pathogen risk list. Available at: http://www.frac.info/docs/defaultsource/publications/pathogen-risk/pathogen-risk-list.pdf.

Furlan, C. R. C., Dantas, A. C. D. M., Denardi, F., Becker, W. F., and Mantovani, A. 2010. Resistência genética dos acessos do banco de germoplasma de macieira da Epagri à mancha foliar de Glomerella (Colletotrichum gloeosporioides). Rev. Bras. Frutic. 32:507-514.

Gisi, U., Sierotzki, H., Cook, A., and Mccaffery, A. 2002. Mechanisms influencing the evolution of resistance to Qo-inhibitor fungicides. Pest Manag. Sci. 58:859-867.

Goes, A., and Kimati, H. 1998. Colletotrichum acutatum, the causal agent of postbloom fruit drop: resistant or insensitive to benomyl? Summa Phytopathol. 24:246-253.

González, E., and Sutton, T. B. 2004. Population diversity within isolates of Colletotrichum spp. causing Glomerella leaf spot and Bitter rot of apples in three orchards in North Carolina. Plant Dis. 88:1335-1340.

González, E., Sutton, T. B., and Correl, J. C. 2006. Clarification of the etiology of Glomerella leaf spot and bitter rot of apple caused by Colletotrichum spp. based on morphology and genetic, molecular and pathogenicity tests. Phytopathology 96:982-992.

Gullino, M. L., Tinivella, F., Garibaldi, A., Kemmitt, G. M., Bacci, L., and Sheppard, B. 2010. Mancozeb: Past, Present, and Future. Plant Dis. 94: 1076-1087.

Hamada, N. A. 2013. Epidemiologia da mancha foliar de Glomerella em macieira. Curitiba, Brazil:Federal University of Parana, PhD thesis.

Hamada, N. A., Katsurayama, Y., and Dantas, A. C. M. 2009. Sensibilidade "in vitro" ao benomyl por isolados de Colletotrichum spp. associados à mancha da gala em macieira. Trop. Plant Pathol. 34:347-351.

Hamada, N. A., and May De Mio, L. L. 2017. Survival of pathogenic Colletotrichum isolates on dormant buds, twigs and fallen leaves of apple trees in commercial orchards. Fruits 72:158-165.

Hamada, N. A., Nesi, C. N., Alves, G., and May De Mio, L. L. 2012. Fungicidas associados ou não a fosfitos no controle da mancha foliar de glomerella em macieira. Rev. Bras. Cienc. Agrar. 7:831-837.

Hwang, S. Y., Kim, H. R., Kim, J. H., Park, J. H., Lee, S. B., Cheong, S. R., and Kim, H. T. 2010. Sensitivity of Colletotrichum spp. isolated from Grapes in Korea to carbendazim and the mixture of carbendazim plus diethofencarb. Plant Pathol. J. 26:49-56.

IAPAR (Instituto Agronômico do Paraná). 2008. Nova Cultivar de Maçã para climas quentes. Available in: <http://www.iapar.br/modules/noticias/article.php? storyid=271>. 7 October 2017.

Ishii, H. 2015. Stability of resistance. In Ishii, H., and Hollomon, W. (Eds.), Fungicide resistance in plant pathogens. Japan: National Institute for AgroEnviromental Sciences, pp. 35-48.

Ishii, H., Yano, K., Date, H., Furuta, A., Sagehashi, Y., Yamaguchi, T., Sugiyama, T., Nishimura, K., and Hasama, W. 2007. Molecular characterization and diagnosis of QoI resistance in cucumber and eggplant fungal pathogens. Phytopathology 97:1458-1466.

Kaneko, Y., Suzuki, T., and Takeuchi, T. 2010. Occurrence and control of anthracnose on Japanese pear caused by Glomerella cingulata. CAFRC Res Bull. 2:7-16.

Katsurayama, Y., and Bonetti, J. I. S. 2009. Manejo das doenças de verão da macieira no sul do Brasil. Pages 45-64 in: Manejo integrado de doenças da macieira. M. J. Stadnik, ed. Universidade Federal de Santa Catarina, Florianópolis.

Kim, Y. S., Min, J. Y., Kang, B. K., Bach, N. V., Choi, W. B., Park, E. W., and Kim, H. T. 2007. Analyses of the less benzimidazole-sensitivity of the isolates of Colletotrichum spp. causing the anthracnose in pepper and strawberry. Plant Pathol. J. 23:187-192.

Kumar, A. S., Reddy, N. P. E., Reddy, K. H., and Devi, M. C. 2007. Evaluation of fungicidal resistance among Colletotrichum gloeosporioides isolates causing mango anthracnose in agri export zone of Andhra Pradesh, India. Plan Pathol. Bull. 16:157-160.

Leite, J. R., Tsuneta, M., and Kishino, A. Y. 1988. Ocorrência de mancha foliar de Glomerella em macieira no Estado do Paraná. IAPAR, Londrina.

Lesniak, K. E., Proffer, T. J., Beckerman, J. L., and Sudin, G. W. 2011. Occurrence of QoI resistance and detection of th G143A mutation in Michigan populations of Venturia inaequalis. Plant Dis. 95:927-934.

Ling, J., Peng, A., Song, X., and Chen, X. 2010. Bioassay of 17 fungicides agains Colletotrichum gloeosporioides Penz. Guangdong Agricultural Sciences. 1.

Ma, Z., Felts, D., and Michailides, T. 2005. Advances in understanding molecular mechanisms of fungicide resistance and molecular detection of resistant genotypes in phytopathogenic fungi. Crop Prot. 24:853-863.

Moreira, R. R., and May De Mio, L. L. 2015. Potential biological agents isolated from apple fail to control Glomerella leaf spot in the field. Biol. Control 87: $56-63$

Moreira, R. R., Nesi, C. N., and May De Mio, L. L. 2014. Bacillus spp. and Pseudomonas putida as inhibitors of the Colletotrichum acutatum group and potential to control Glomerella leaf spot. Biol. Control 72:30-37.

Moreira, R. R., Peres, N. A., and May De Mio, L. L. 2019. Colletotrichum acutatum and $C$. gloeosporioides species complex associated with apple in Brazil. Plant Dis. 103:268-275.

Munir, M., Amsden, E., Dixon, E., Vaillancourt, L., and Ward Gauthier, N. A. 2016. Characterization of Colletotrichum species causing bitter rot of apple in Kentucky orchards. Plant Dis. 100:2194-2203.

Peres, N. A. R., Souza, N. L., Peever, T. L., and Timmer, L. W. 2004. Benomyl sensitivity of isolates of Colletotrichum acutatum and C. gloeosporioides from citrus. Plant Dis. 88:125-130.

R Core Team. 2013. R: A language \& environment for statistical computing Vienna: R Foundation for Statistical Computing. http://www.R-project.org/.

Shi, Y., Correll, C., Guerber, C., and Rom, R. 1996. Frequency of Colletotrichum species causing bitter rot of apple in the southeastern United States. Plant Dis. 80:692-696.

Stadnik, M. J., Araújo, L., and Valdebenito-Sanhueza, R. M. 2009. Estratégias alternativas de controle da mancha foliar de glomerella e da sarna da macieira. Pages 105-126 in: Manejo integrado de doenças da macieira. M. J. Stadnik, ed. CCAUFSC, Florianópolis.

Sutton, B. C., Bailey, J. A., and Jeger, M. J. 1992. The genus Glomerella and its anamorph Colletotrichum. Pages 1-26 in: Colletotrichum: biology, pathology and control. Bayley, J. A., and Jeger, M. J., eds. CABI, Wallingford.

Sutton, T. B., and Sanhueza, R. M. V. 1998. Necrotic leaf blotch of Golden delicious e Glomerella leaf spot: a resolution of common names. Plant Dis. 82:267-268.

Suvarna, J., Basha, S. T., Hemalatha, T. M., and Reddy, N. P. E. 2009. Efficacy of fungicides against Colletotrichum gloeosporioides causing mango anthracnose. Indian J. Plant Prot. 37:201-203.

Tam, G., Li, Z., Xue, L., and Li, L. 2008. Influence of propiconazole and Bacillus subtitle B-24 on the control effect of postharvest anthracnose of apple fruit. Acta Laser Biology Sinica. 2.

Tamura, K., Peterson, D., Peterson, N., Stecher, G., Nei, M., and Kumar, S. 2011 MEGA5: molecular evolutionary genetics analysis using maximum likelihood, evolutionary distance, and maximum parsimony methods. Mol. Biol. Evol. 28 : 2731-2739.

Tashiro, N., Manabe, K., and Ide, Y. 2012. Emergence and frequency of highly benzimidazole-resistant Colletotrichum gloeosporioides, pathogen of Japanese pear anthracnose, after discontinued use of benzimidazole. J. Gen. Plant Pathol. 78:221-226.

Taylor, J. A. 1971. Necrotic Leaf Blotch and fruit rot of apple caused by a strain of Glomerella cingulata. Phytopathology 61:221-224.

Velho, A. C., Alaniz, S., Casanova, L., Mondino, P., and Stadnik, M. J. 2015. New insights into the characterization of Colletotrichum species associated with apple diseases in southern Brazil and Uruguay. Fungal Biol. 119: 229-244

Vielba-Fernández, A., Bellón-Gómez, D. B., and Torés, J. A. 2018. Heteroplasmy for the cytochrome b gene in Podosphaera xanthii and its role in resistance to QoI fungicides in Spain. Plant Dis. 102:1599-1605.

Watanabe, H., Horinouchi, H., Muramoto, Y., and Ishii, H. 2017. Occurrence of azoxystrobin-resistant isolates in Passalora fulva, the pathogen of tomato leaf mould disease. Plant Pathol. 66:1472-1479.

Wheeler, I. E., Kendall, S. J., Butters, J., Hollomon, D. W., and Hall, L. 1995 Using allele-specific oligonucleotide probes to characterize benzimidazole resistance in Rhynchosporium secalis. Pestic. Sci. 43:201-209.

Wong, F. P., Cerda, K., and Hernandez-Martinez, R. 2008. Detection and characterization of benzimidazole resistance in California populations of Colletotrrichum cereale. Plant Dis. 92:239-246.

Yokosawa, S., Egushi, N., Kondo, K., and Sato, T. 2017. Phylogenetic relationship and fungicide sensitivity of members of the Colletotrichum gloeosporioides species complex from apple. J. Gen. Plant Pathol. 83:291-298.

Young, J. R., Tomaso-Peterson, M., Tredway, L. P., and Cerda, K. 2010. Two mutations in $\beta$-tubulin 2 gene associated with Thiophanate-methyl resistance in Colletotrichum cereale isolates from creeping bentgrass in Mississippi and Alabama. Plant Dis. 94:207-212.

Zhang, R., Wang, S. F., Cui, N. J. Q., and Sun, G. Y. 2008. First report of bitter rot caused by Colletotrichum acutatum on apple in China. Plant Dis. 92:1474. 